\title{
HEALTH BENEFITS RELATED TO THE REDUCTION OF PM CONCENTRATION IN AMBIENT AIR, SILESIAN VOIVODESHIP, POLAND
}

MICHAŁ KOWALSKI ${ }^{1}$, KATARZYNA KOWALSKA ${ }^{2}$, and MALGORZATA KOWALSKA ${ }^{3}$

${ }^{1}$ Silesian University of Technology, Gliwice, Poland

Faculty of Energy and Environmental Engineering, Department of Air Protection

${ }^{2}$ Silesian University of Technology, Gliwice, Poland

Faculty of Energy and Environmental Engineering, Environmental Biotechnology Department

${ }^{3}$ Medical University of Silesia, Katowice, Poland

Medical Faculty, Department of Epidemiology

\begin{abstract}
Objectives: Health Impact Assessments (HIA) approach can be executed by calculating the attributable burden of disease. The most common indicators used in the HIA methodology are: premature mortality, morbidity, life-expectancy, and Disability Adjusted Life-Year (DALY). The term Disability Adjusted Life-Years (DALYs) indicates months/years lost due to a premature death or disability. The aim of the study was to present health benefits, expressed in terms of lower total mortality and cardio-respiratory hospitalization rates, due to a decreased particulate matter (PM) concentration in ambient air, in Silesian voivodeship. Material and Methods: In this paper, results obtained from the APHEKOM (Improving Knowledge and Communication for Decision Making on Air Pollution and Health in Europe) project, which provided specialized HIA tools, useful for assessing health benefits resulting from reducing air pollution, were used. Both short-term and long-term exposure HIA tools were applied with regard to the appropriate data for Silesian voivodeship. Exposure data were obtained from the Regional Environmental Inspectorate in Katowice, while population and health data were obtained from the Central Statistical Office of Poland or from the Silesian Voivodeship Office, respectively. Results: Health benefits that are related to an improvement of ambient air quality in Silesia region are similar to previous estimates obtained for Kraków city. The reduction of short-term exposure to $\mathrm{PM}_{10}$ by $5 \mu \mathrm{g} / \mathrm{m}^{3}$ results in a lower number of yearly non-external deaths $(2.6-2.75$ per 100000 inhabitants). This effect was also shown to be similar in the city of Zabrze, as well as in the whole Silesia region. Conclusions: The Health Impact Assessments tools developed by the World Health Organization (WHO) can help public health experts make decisions in order to improve the health of populations living in particular regions of Europe.
\end{abstract}

Key words:

Short-term exposure, Long-term exposure, HIA procedure, PM in ambient air, Total mortality, Cardio-respiratory hospitalization

\section{INTRODUCTION}

Ambient air pollution is a well-known global problem, which results in many negative short-term and/or longterm health effects. Current reports of the European
Environment Agency (EEA) and Environmental Protection Agency in USA (US EPA) suggest that particulate matter (PM) and ozone constitute a serious problem [1,2]. There are 2 reasons for such a situation. First,

Michał Kowalski and Katarzyna Kowalska are scholars of DoktoRIS - Scholarschip Program for Innovative Silesia, co-financed by the European Union under the European Social Fund.

Received: October 22, 2014. Accepted: April 13, 2015.

Corresponding author: M. Kowalski, Silesian University of Technology, Faculty of Power and Environmental Engineering, Department of Air Protection, Konarskiego 22B, 44-100 Gliwice, Poland (e-mail: michal.kowalski@polsl.pl). 
the size of exposed population is large and it is still growing due to the increasing urbanization and intensive development of traffic. The $2 \mathrm{nd}$ is the use of inexpensive fuel materials for heating, especially in the poorest regions of the world.

The World Health Organization (WHO) estimated the attributable death to outdoor air pollution in Poland in the year 2008 to be 6600 deaths (17/100 000 inhabitants). This value was higher, compared to the calculated values for neighboring countries such as Czech Republic (14/100 000 inhabitants) or Slovakia (9/100 000 inhabitants) [3].

The impact of air quality on human health has been well documented in numerous publications based on scientific evidence. Among the well-known health problems associated with short-term exposure to particulate air pollution are acute effects, such as: an increase in the daily number of hospital admissions and an increase in the daily number of deaths. Short-term negative effects include: adverse effects on the cardiovascular system [4-6], and lung inflammatory reactions or respiratory symptoms [7-9]. These health problems lead to the increased emergency department visits [10]. Furthermore, the 2nd group of long term effects includes impaired lung development in children [11], an increase in asthma incidence [7,10,12], chronic obstructive pulmonary disease, cancer [13] and potential decrease in life expectancy [5]. Although the dominant mechanism of the damage is not yet unambiguously resolved, we can observe deterioration of principal vital statistics in the population associated with a worse quality of ambient air.

Health Impact Assessments (HIA) approach can be executed by calculating the attributable burden of disease. The most common indicator used in this approach is premature mortality. Other indicators are: morbidity, life-expectancy, and more recently, popular Disability Adjusted Life-Year (DALY). The term Disability Adjusted Life-Years (DALYs) indicates months/years lost due to a premature death or disability. Results of some studies, published in the WHO reports, have shown that ambient air pollution is the $3 \mathrm{rd}$, after occupational exposure and road traffic accidents, highest cause of DALYs in the developed countries [14,15].

The Health Impact Assessments procedure consist in defining the risk (e.g., connected with exposure to air pollution), assumption of scenarios of reducing hazardous substances and estimating the monetary or health benefits of achieving the goals stated in the reduction scenarios. The objective of the HIA procedure is to apply existing knowledge and evidence on health impacts to specific social and community contexts. Results received by HIA are presented to decision makers and stakeholders in order to focus on maximizing the proposal's positive health effects, and minimizing the negative ones [16].

The Health Impact Assessments procedure has been used in many projects, such as CAFE (Clean Air for Europe), APHEIS (Air Pollution and Health: A European Information System), APHEA (Air Pollution and Health: A European Approach) and APHEKOM (Improving Knowledge and Communication for Decision Making on Air Pollution and Health in Europe) to assess air pollution impact on public health in European cities, which has been summarized in numerous reports [1720]. It is worth noting that Poland did not participate in majority of those projects, except for the APHEIS project, where Kraków was one of the project cities [17]. The World Health Organization supervises the programs which put emphasis on health impact. The World Health Organization provides specialized HIA tools for health experts in order to enable them to perform an analysis of potential health effects and thus, to identify vulnerable groups. Furthermore, those tools are provided to policy makers in order to set adequate regulations.

The aim of this study is to present health benefits expressed in terms of the lower total mortality and cardiorespiratory hospitalization rates due to a decrease in fine dust $\left(\mathrm{PM}_{10}\right.$ and $\left.\mathrm{PM}_{2.5}\right)$ concentration in ambient air in 
Silesian voivodeship. The Health Impact Assessments procedure was used due to the lack of such data in the Silesia region - a highly urbanized and industrialized voivodeship in the southern part of Poland. The Silesian region has been struggling with high concentrations of air pollutants and poor quality of ambient air for many years. In the recent period, the increased social anxiety caused by deterioration of air quality, especially in the heating season, underscores the importance to estimate potential health benefits associated with, even the smallest, improvement in air quality.

\section{MATERIAL AND METHODS}

\section{Exposure data}

Data on the daily concentrations of $\mathrm{PM}_{10}$ and $\mathrm{PM}_{2.5}$ with regard to exposure in Silesian voivodeship in particular years were obtained from the Regional Environmental Inspectorate in Katowice. Dust concentrations were measured using automatic measuring stations located in the voivodeship within the regional air quality monitoring programs. Finally, complete exposure data (in accordance with the methodology - a complete data set covered $75 \%$ of measured daily fine particulate concentrations per year) were obtained for years 2003, 2005 and 2012 for $\mathrm{PM}_{10}$. However, $\mathrm{PM}_{2.5}$ concentration data were available only for Zabrze city, but the data for Silesian voivodeship represent average-area values available only for 2005 and 2012.

\section{Population and health data}

Data concerning hospital admissions within the population living in Silesian voivodeship and, separately in Zabrze city, over the years 2003, 2005, and 2012, were obtained from the Silesian Voivodeship Office, Department for Health Care System Supervision. According to the HIA methodology, the data regarded the number of hospital admissions due to cardiac diseases (I00-I52 according to the International Statistical Classification of
Diseases and Related Health Problems, 10th revision ICD-10) in the total population. However, respiratory hospitalization data concerned the number of cases in the total population (J00-J99 according to ICD-10), and separately in population aged 15-64 years and older ( $\geq 65$ years).

The data on the total non-external deaths of Silesian inhabitants were obtained from the Central Statistical Office of Poland. Likewise, data describing the age structure of Silesian voivodeship and Zabrze city population were acquired from the local data bank displayed on the Central Statistical Office website.

This paper employs the use of the HIA calculator to assess potential health benefits of reducing fine particulate matter concentrations $\left(\mathrm{PM}_{10}\right.$ and $\left.\mathrm{PM}_{2.5}\right)$. The tools proposed by WHO and that were developed during the APHEKOM project (both cases: short- and long-term effects calculators) [21,22], were used in this study. By using the WHO tools described above, it was possible to calculate the short- and long-term impact of air pollution. Both, short and long term impact of air pollution require providing basic data concerning exposure (daily concentration of ambient air pollution), population data (involving age structure of a population) and health data (e.g., total non-external deaths, deaths due to cardiovascular and respiratory diseases and cardiac hospital admissions, I00-I52, according to ICD-10).

Advantages of the tools used in the APHEKOM project include simplicity and the ability to use them free of charge. Moreover, the results obtained by the use of the applicable tools are accepted by WHO. Two scenarios of $\mathrm{PM}_{10}$ reduction were examined according to the WHO Air Quality Guideline. First, decreasing the annual mean $\mathrm{PM}_{10}$ concentration by $5 \mu \mathrm{g} / \mathrm{m}^{3}$, and the $2 \mathrm{nd}$ - decreasing the annual mean $\mathrm{PM}_{10}$ concentration to $20 \mu \mathrm{g} / \mathrm{m}^{3}$.

In the case of $\mathrm{PM}_{2.5}$, long-term tools were used in 2 scenarios. The 1st scenario involved decreasing the annual mean $\mathrm{PM}_{2.5}$ concentration by $5 \mu \mathrm{g} / \mathrm{m}^{3}$, while the 
2nd - involved decreasing the annual mean $\mathrm{PM}_{2.5}$ concentration to $10 \mu \mathrm{g} / \mathrm{m}^{3}$. Dose response data, necessary to estimate health benefits related to reduction of PM concentration, were taken from Pope et al. publications [23,24]. Due to the availability of $\mathrm{PM}_{10}$ exposure data and health effects only for some periods, it was possible to calculate health benefits as a reduced number of total deaths and hospitalizations due to respiratory and cardiac diseases related to improving air quality in the short-term exposure in Zabrze and Silesian voivodeship (only for selected years 2005 and 2012 in Zabrze and 2003 in Silesian voivodeship). Furthermore, health benefits related to $\mathrm{PM}_{2.5}$ exposure in the long-term (just total mortality) were obtained for Silesian voivodeship in 2005 and for Zabrze city in 2012.

\section{RESULTS}

Table 1 shows descriptive statistics required in the HIA tools, covering exposure and health data in both of the study regions: Zabrze city and Silesian voivodeship. Figure 1 shows an example of daily $\mathrm{PM}_{2.5}$ concentrations in Zabrze city in 2012. A similar distribution of concentrations with a minimum dust concentration $\left(\mathrm{PM}_{10}\right.$ or $\mathrm{PM}_{2.5}$ levels) attributable to spring and summer months, and

Table 1. Descriptive health and environment statistics in the region of the study

\begin{tabular}{|c|c|c|c|}
\hline $\begin{array}{c}\text { Year } \\
\text { of the study }\end{array}$ & Variable & Zabrze city & $\begin{array}{c}\text { Silesian } \\
\text { voivodeship }\end{array}$ \\
\hline \multirow[t]{6}{*}{2003} & total population $[\mathrm{n}]$ & 193665 & 4714982 \\
\hline & total non-external deaths $[\mathrm{n}]$ & 1562 & 42472 \\
\hline & total cardiac hospitalizations (I00-I52) [n] & 2654 & 102144 \\
\hline & total respiratory hospitalizations (J00-J99) [n] & 1866 & 59285 \\
\hline & $\mathrm{PM}_{10}$ daily concentration $\left[\mu \mathrm{g} / \mathrm{m}^{3}\right](\mathrm{M} \pm \mathrm{SD})$ & nemd & $39 \pm 25$ \\
\hline & $\mathrm{PM}_{2.5}$ daily concentration $\left[\mu \mathrm{g} / \mathrm{m}^{3}\right](\mathrm{M} \pm \mathrm{SD})$ & nemd & nemd \\
\hline \multirow[t]{6}{*}{2005} & total population [n] & 191247 & 4685775 \\
\hline & total non-external deaths $[\mathrm{n}]$ & 1673 & 43183 \\
\hline & total cardiac hospitalizations (I00-I52) [n] & 2962 & 106966 \\
\hline & total respiratory hospitalizations (J00-J99) [n] & 1936 & 66125 \\
\hline & $\mathrm{PM}_{10}$ daily concentration $\left[\mu \mathrm{g} / \mathrm{m}^{3}\right](\mathrm{M} \pm \mathrm{SD})$ & $56 \pm 52$ & nemd \\
\hline & $\mathrm{PM}_{2.5}$ daily concentration $\left[\mu \mathrm{g} / \mathrm{m}^{3}\right](\mathrm{M} \pm \mathrm{SD})$ & nemd & $32 \pm 30$ \\
\hline \multirow[t]{8}{*}{2012} & total population [n] & 179452 & 4615870 \\
\hline & population aged $<30$ years $[\mathrm{n}]$ & nemd & nemd \\
\hline & population aged $\geq 30$ years $[\mathrm{n}]$ & 139179 & 3535872 \\
\hline & total non-external deaths $[\mathrm{n}]$ & 1654 & 46060 \\
\hline & total cardiac hospitalizations (I00-I52) [n] & 3131 & 106301 \\
\hline & total respiratory hospitalizations (J00-J99) [n] & 1988 & 58359 \\
\hline & $\mathrm{PM}_{10}$ daily concentration $\left[\mu \mathrm{g} / \mathrm{m}^{3}\right](\mathrm{M} \pm \mathrm{SD})$ & $61 \pm 58$ & nemd \\
\hline & $\mathrm{PM}_{25}$ daily concentration $\left[\mu \mathrm{g} / \mathrm{m}^{3}\right](\mathrm{M} \pm \mathrm{SD})$ & $34 \pm 36$ & $39 \pm 45$ \\
\hline
\end{tabular}

$\mathrm{PM}$ - particulate matter; M - mean; SD - standard deviation.

nemd - not enough measurement data for the Health Impact Assessments (HIA) tool. 


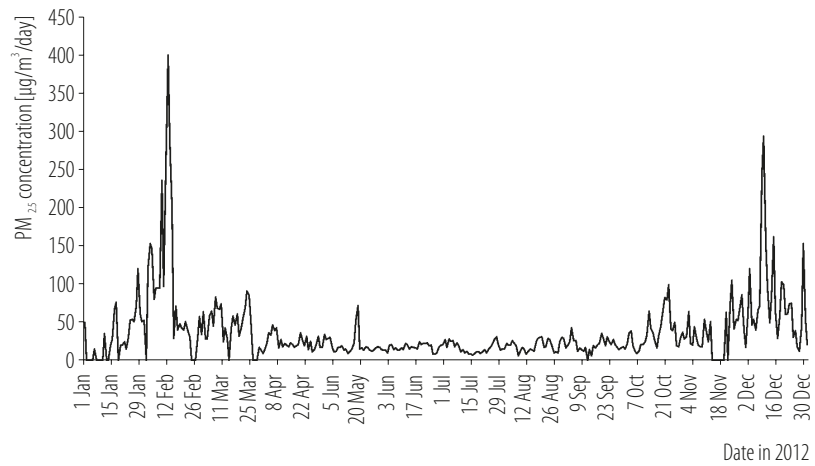

Fig. 1. Daily particulate matter $\left(\mathrm{PM}_{2.5}\right)$ concentrations in Zabrze city, 2012

with a maximum concentration recorded in a cold season (fall-winter) covered all the cities located in Silesian voivodeship during the whole study period.

Table 2 and 3 represent the results obtained from the use of the HIA calculator. We can observe potential health benefits related to the reduction of annual $\mathrm{PM}_{10}$ and $\mathrm{PM}_{2.5}$ concentration in Zabrze city, and in the entire Silesian voivodeship. The presented data describe 2 scenarios of dust reduction (by $5 \mu \mathrm{g} / \mathrm{m}^{3}$ and to $10 \mu \mathrm{g} / \mathrm{m}^{3}$ or $20 \mu \mathrm{g} / \mathrm{m}^{3}$ ) in the long- and short-term exposure of population for the following years: 2003, 2005 and 2012 as a reference. It should be noted that even a slight improvement in the air quality (taking into account the reduction of short-term exposure of $\mathrm{PM}_{10}$ by $5 \mu \mathrm{g} / \mathrm{m}^{3}$ ) brings along similar health benefits, which is represented in a form of a lower number of yearly non-external deaths per 100000 inhabitants in the following years (2.7 in Silesian voivodeship in 2003 and 2.6 or 2.75 in 2005 or in 2012 in Zabrze city), both in the whole Silesian voivodeship and in Zabrze city, respectively.

If we assume a more significant improvement in the air quality (reduction in concentration of $\mathrm{PM}_{10}$ to $20 \mu \mathrm{g} / \mathrm{m}^{3}$ ) health benefit expressed as the avoided annual number of non-external deaths is greater in Zabrze city than in all the voivodeship. Similarly, better results are achieved for the estimated number of hospital admissions due to cardiopulmonary causes for the residents of Zabrze city than for the inhabitants of the whole Silesian voivodeship. According to the calculations, taking 100000 people living in Silesian voivodeship, 32.8 hospitalizations due to respiratory disease and 30 hospitalizations due to cardiac disease in 2003 could have been avoided. Improvement in the air quality in Zabrze brings along 50.4 hospitalizations per 100000 inhabitants due to respiratory diseases and 42.3 due to cardiac diseases. It is also worth noting that in the case of long-term exposure to fine dust $\left(\mathrm{PM}_{2.5}\right)$, the improvement of air quality by up to $5 \mu \mathrm{g} / \mathrm{m}^{3}$ gives a health gain in a form of nearly 5 (4.8) months or 11 (10.8) months of additional life per capita in both

Table 2. Health Impact Assessments (HIA), a long term exposure procedure - potential health benefits related to the reduction of annual particulate matter $\left(\mathrm{PM}_{2.5}\right)$ concentration in Zabrze city or in Silesian voivodeship

\begin{tabular}{|c|c|c|c|c|c|}
\hline \multirow{2}{*}{$\begin{array}{l}\text { Region, year } \\
\text { of the study }\end{array}$} & \multirow{2}{*}{$\begin{array}{c}\text { Scenario of } \\
\text { decrease of } \mathrm{PM}_{2.5} \\
\text { concentration } \\
{\left[\mu \mathrm{g} / \mathrm{m}^{3}\right]}\end{array}$} & \multicolumn{2}{|c|}{$\begin{array}{c}\text { Annual non-external deaths avoided } \\
{[\mathrm{n}]}\end{array}$} & \multirow{2}{*}{$\begin{array}{c}\text { Gain in life } \\
\text { expectancy } \\
\text { [months/person } \\
\text { aged } \geq 30 \text { years] }\end{array}$} & \multirow{2}{*}{$\begin{array}{c}\text { Gain in life } \\
\text { in population } \\
\text { aged } \geq 30 \text { years } \\
\text { [years] }\end{array}$} \\
\hline & & $\begin{array}{l}\text { in total population } \\
\text { aged } \geq 30 \text { years }\end{array}$ & $\begin{array}{c}\text { per } 100000 \\
\text { inhabitants aged } \\
\geq 30 \text { years }\end{array}$ & & \\
\hline \multirow{2}{*}{$\begin{array}{l}\text { Silesian voivodeship, } \\
2012\end{array}$} & by 5 & 866.3 & 30.1 & 4.8 & 26502.9 \\
\hline & to 10 & 3686.5 & 128.1 & 21.7 & 121279.0 \\
\hline \multirow[t]{2}{*}{ Zabrze city, 2012} & by 5 & 16.6 & 13.9 & 10.8 & 2467.7 \\
\hline & to 10 & 90.0 & 75.6 & 66.8 & 15303.2 \\
\hline
\end{tabular}

$\mathrm{PM}$ - particulate matter. 
Table 3. Results of the Health Impact Assessments (HIA), a short term exposure procedure - potential health benefits related to the reduction of annual particulate matter $\left(\mathrm{PM}_{10}\right)$ concentration in Zabrze city or in Silesian voivodeship

\begin{tabular}{|c|c|c|c|c|c|}
\hline \multirow{2}{*}{$\begin{array}{l}\text { Region, year } \\
\text { of the study }\end{array}$} & \multirow{2}{*}{$\begin{array}{c}\text { Scenario of } \\
\text { decrease of } \mathrm{PM}_{10} \\
\text { concentration } \\
{\left[\mu \mathrm{g} / \mathrm{m}^{3}\right]}\end{array}$} & \multicolumn{2}{|c|}{$\begin{array}{l}\text { Annual non-external deaths avoided } \\
{[\mathrm{n}]}\end{array}$} & \multirow{2}{*}{$\begin{array}{c}\text { Annual hospitalizations due } \\
\text { to respiratory diseases } \\
(\mathrm{I} 00-\mathrm{I} 99) \\
{[\mathrm{n}(\mathrm{n} / 100000)]}\end{array}$} & \multirow{2}{*}{$\begin{array}{c}\text { Annual hospitalizations due } \\
\text { to cardiac diseases } \\
(\mathrm{I} 00-\mathrm{I} 52) \\
{[\mathrm{n}(\mathrm{n} / 100000)]}\end{array}$} \\
\hline & & $\begin{array}{l}\text { in total } \\
\text { population }\end{array}$ & $\begin{array}{l}\text { per } 100000 \\
\text { inhabitants }\end{array}$ & & \\
\hline \multirow{2}{*}{$\begin{array}{l}\text { Silesian } \\
\text { voivodeship, } \\
2003\end{array}$} & by 5 & 126.8 & 2.70 & $334.6(7.1)$ & $305.1(6.5)$ \\
\hline & to 20 & 588.4 & 12.50 & $1544.7(32.8)$ & $1415.2(30)$ \\
\hline \multirow{2}{*}{$\begin{array}{l}\text { Zabrze city, } \\
2005\end{array}$} & by 5 & 5.0 & 2.60 & $10.5(5.5)$ & $8.8(4.6)$ \\
\hline & to 20 & 32.6 & 17.00 & $63.8(35.7)$ & $57.7(30.2)$ \\
\hline \multirow{2}{*}{$\begin{array}{l}\text { Zabrze city, } \\
2012\end{array}$} & by 5 & 4.9 & 2.75 & $11.2(6.3)$ & $9.4(5.2)$ \\
\hline & to 20 & 40.1 & 22.35 & $90.4(50.4)$ & $75.9(42.3)$ \\
\hline
\end{tabular}

PM - particulate matter.

populations aged $\geq 30$ years (Silesian voivodeship or Zabrze city).

Differences between the results obtained for Zabrze and the whole Silesian voivodeship in the case of long-term exposure may be related to slightly higher concentrations of fine PM fraction $\left(\mathrm{PM}_{2.5}\right)$ in the total voivodeship than in the city of Zabrze. Hypothetically, reducing $\mathrm{PM}_{2.5}$ concentration should result in obtaining a slightly better health outcome. In the case of short-term exposure related to $\mathrm{PM}_{10}$ concentration, results of the 1 st reduction scenario (reducing the daily mean concentrations by $5 \mu \mathrm{g} / \mathrm{m}^{3}$ ) are very comparable. The second scenario, in which more strict reduction is being considered, shows that in the city of Zabrze, where daily mean $\mathrm{PM}_{10}$ concentration is much higher (56-61 $\mu \mathrm{g} / \mathrm{m}^{3}$ vs. $39 \mu \mathrm{g} / \mathrm{m}^{3}$ in Silesian voivodeship), a considerably better health outcome could be observed.

\section{DISCUSSION}

Results of an earlier study in a similar, in terms of age, population living in Kraków suggest that the reduction of annual mean $\mathrm{PM}_{2.5}$ by $5 \mu \mathrm{g} / \mathrm{m}^{3}$ would result in 3.9 deaths due to cardiovascular diseases per 100000 population in relation to the cumulative exposure (up to 40 days), and at the same time would increase life expectancy by additional 8 months [25]. An important observation is that health benefits related to the improvement of ambient air quality are similar in Silesia region and Kraków, and they do not depend on the period of study.

Actual data suggest that the reduction in $\mathrm{PM}_{2.5}$ exposure (related to road traffic) in the general population of Barcelona could result in 7 cases of low birth weight, 6 cases of preterm birth, 1 case of cardiovascular disease and 1 case of lower respiratory tract infection a year [26]. A similar study conducted in London has concluded that health benefits of cycling in the central city are much higher in older adults than in the youngest people, and $\mathrm{PM}_{2.5}$ concentration basically does not affect the value of DALYs [27]. Other currently published data indicate that black carbon (road traffic pollution indicator) is responsible for reducing life expectancy of populations approximately by 4-9 times more than $\mathrm{PM}_{2.5}$ [28].

On the other hand, estimates regarding 25 European cities suggest the health burden on their inhabitants aged $\geq 30$ years could be attributed to the chronic exposure to $\mathrm{PM}_{2.5}$, about 22 months loss of life expectancy a year with each increase of the WHO guideline to $10 \mu \mathrm{g} / \mathrm{m}^{3}$. However, the authors themselves emphasize that the value depends on the city [20]. Some authors consider that 
the improvement of ambient air quality simultaneous with an increase in physical activity of residents (e.g., through biking) can lead to a drastic reduction in health and economic costs in the United States [29].

As previously mentioned, the results obtained should be treated with caution. In fact, the HIA procedure is based on numerous assumptions describing exposure, dose-response relationship and excludes only particular factors of the environment (here just $\mathrm{PM}_{10}$ or $\mathrm{PM}_{2.5}$ concentration in ambient air). Furthermore, the lack of complete monitoring data or health statistics makes it difficult to observe temporal variability in the selected period and the chosen regions.

Despite those limitations, it is worth to utilize the tools developed by WHO because they can help public health experts make decisions to improve the health of populations living in particular regions. This is particularly important in Silesian voivodeship, a region which has a population close to 4 million people. Furthermore, the described calculation procedure probably works better in the case of a larger population and availability of complete population and environmental data. Our observation confirmed the importance of proper data monitoring for the purpose of implementation of tasks within the area of environmental health.

\section{CONCLUSIONS}

The Health Impact Assessments tools developed by the World Health Organization (WHO) can help public health experts make decisions in order to improve health of populations living in particular regions of Europe.

\section{REFERENCES}

1. European Environment Agency. The European environment - State and outlook 2010. Synthesis. Copenhagen: Rosendahls-Schultz Grafisk; 2010.

2. United States Environmental Protection Agency. Air quality criteria for particulate matter (Final report, Oct 2004).
Washington (DC): The Agency; 2004 [cited 2014 Sep 30]. Available from: http://cfpub2.epa.gov/ncea/cfm/recordisplay. cfm?deid $=87903$.

3. World Health Organization [Internet]. Health statistics and information systems: Estimates for 2000-2012. Disease burden. By country: DALY estimates, 2000-2012. Geneva: The Organization; 2014 [cited 2014 Sep 30]. Available from: http://www.who.int/healthinfo/global_burden_disease/estimates/en/index2.html.

4. Pope CA 3rd, Muhlestein JB, May HT, Renlund DG, Anderson JL, Horne BD. Ischemic heart disease events triggered by short-term exposure to fine particulate air pollution. Circulation. 2006;114(23):2443-8, http://dx.doi. org/10.1161/CIRCULATIONAHA.106.636977.

5. Pope CA 3rd, Burnett RT, Krewski D, Jerrett M, Shi Y, Calle EE, et al. Cardiovascular mortality and exposure to airborne fine particulate matter and cigarette smoke: Shape of the exposure-response relationship. Circulation. 2009;120(11):941-8, http://dx.doi.org/10.1161/CIRCULATIONAHA.109.857888.

6. Lokken RP, Wellenius GA, Coull BA, Burger MR, Schlaug G, Suh HH, et al. Air pollution and risk of stroke: Underestimation of effect due to misclassification of time of event onset. Epidemiology. 2009;20(1):137-42.

7. Clark NA, Demers PA, Karr CJ, Koehoorn M, Lencar C, Tamburic L, et al. Effect of early life exposure to air pollution on development of childhood asthma. Environ Health Perspect. 2010;118(2):284-90, http://dx.doi.org/10.1289/ehp. 0900916.

8. Zanobetti A, Bind MA, Schwartz J. Particulate air pollution and survival in a COPD cohort. Environ Health. 2008;7:48, http://dx.doi.org/10.1186/1476-069X-7-48.

9. Ségala C, Poizeau D, Mesbah M, Willems S, Maidenberg M. Winter air pollution and infant bronchiolitis in Paris. Environ Res. 2008;106(1):96-100, http://dx.doi.org/10.1016/j.envres.2007.05.003.

10. Abelsohn A, Stieb DM. Health effects of outdoor air pollution. Approach to counseling patients using the Air Quality Health Index. Can Fam Physician. 2011;57(8):881-7. 
11. Gauderman WJ, Avol E, Gilliland F, Vora H, Thomas D, Berhane K, et al. The effect of air pollution on lung development from 10 to 18 years of age. N Engl J Med. 2004;351(11):105767, http://dx.doi.org/10.1056/NEJMoa040610.

12. Brauer M, Lencar C, Tamburic L, Koehoorn M, Demers P, Karr C. A cohort study of traffic-related air pollution impacts on birth outcomes. Environ Health Perspect. 2008;116(5):680-6, http://dx.doi.org/10.1289/ehp.10952.

13. Laden F, Schwartz J, Speizer FE, Dockery DW. Reduction in fine particulate air pollution and mortality: Extended follow-up of the Harvard Six Cities study. Am J Respir Crit Care Med. 2006;173(6):667-72, http://dx.doi.org/10.1164/ rccm.200503-4430C.

14. Hänninen $\mathrm{O}, \mathrm{Knol} \mathrm{A}$, editors. European perspectives on environmental burden of disease estimates for nine stressors in six European countries. Helsinki: University Printing; 2011. p. 5-11.

15. Kowalska M, Skrzypek M. [Environmental burden of disease (EBD) and the possibility of using the method for estimating health effects related to $\mathrm{PM}_{2.5}$ exposure]. Hygeia Public Health. 2014;49(1):33-8. Polish.

16. Taylor L, Blair-Stevens $\mathrm{C}$, editors. Introducing health impact assessment (HIA): Informing the decision-making process [Internet]. London Health Development Agency; 2002 [cited 2014 Sep 30]. Available from: http://hiaconnect.edu.au/ old/files/Introducing_HIA.pdf.

17. Medina S, le Tertre A, Saklad M. The Apheis project: Air Pollution and Health - A European Information System. Air Qual Atmos Health. 2009;2(4):185-98, http://dx.doi. org/10.1007/s11869-009-0050-2.

18. World Health Organization. Health aspects of air pollution. Results from the WHO project: Systematic review of health aspects of air pollution in Europe. Copenhagen: The Organization; 2004 [cited 2014 Sep 30]. Available from: http://www. euro.who.int/_data/assets/pdf_file/0003/74730/E83080.pdf.

19. Katsouyanni K. Aphea project: Air Pollution and Health: A European Approach. Epidemiology. 2006;17(6):S19, http://dx.doi.org/10.1097/00001648-200611001-00003.
20. Pascal M, Corso M, Chanel O, Declecq C, Badaloni C, Cesaroni $\mathrm{G}$, et al. Assessing the public health impact of urban air pollution in 25 European cities: Results of the Aphekom project. Sci Total Environ. 2013;449:390-400, http://dx.doi. org/10.1016/j.scitotenv.2013.01.077.

21. Aphekom HIA short term effects calculator: HIA tool short term (rev. Sep 2013) [Internet]. Saint-Maurice: Aphekom; c2014 [cited 2014 Oct 10]. Available from: http://www. aphekom.org/web/aphekom.org/publications.

22. Aphekom HIA long term effects calculator: HIA tool long term (rev. Sep 2013) [Internet]. Saint-Maurice: Aphekom; c2014 [cited 2014 Oct 10]. Available from: http://www. aphekom.org/web/aphekom.org/publications.

23. Pope CA 3rd, Burnett R, Thun M, Calle E, Krewski D, Ito K, et al. Lung cancer, cardiopulmonary mortality, and long-term exposure to fine particulate air pollution. JAMA. 2002;287(9): 1132-41, http://dx.doi.org/10.1001/jama.287.9.1132.

24. Pope CA 3rd, Hansen ML, Long RW, Nielsen KR, Eatough NL, Wilson WE, et al. Ambient particulate late air pollution, heart rate variability, and blood markers of inflammation in a panel of elderly subjects. Environ Health Perspect. 2004;112(3):339-45.

25. Szafraniec K. Cracow city report [Internet]. Kraków: Jagiellonian University; 2005 [cited 2014 Sep 30]. Available from: http://www.apheis.org/ApheisNewCityReports1.PDF/ Cracow\%2520city\%2520report.pdf.

26. Rojas-Rueda D, de Nazelle A, Teixidó O, Nieuwenhuijsen MJ. Health impact assessment of increasing public transport and cycling use in Barcelona: A morbidity and burden of disease approach. Prev Med. 2013;57(5):573-9, http://dx.doi.org/10.1016/j.ypmed.2013.07.021.

27. Woodcock J, Tainio M, Cheshire J, O'Brien O, Goodman A. Health effects of the London bicycle sparing system: Health impast model ling study. BMJ. 2014;348:g425, http://dx.doi. org/10.1136/bmj.g425.

28. Janssen NAH, Hoek G, Simic-Lawson M, Fischer P, van Bree $\mathrm{L}$, ten Brink $\mathrm{H}$, et al. Black carbon as an additional indicator of the adverse health effects of airborne particles 
compared with $\mathrm{PM}_{10}$ and $\mathrm{PM}_{2.5}$. Environ Health Perspect. 2011;119(12):1691-9, http://dx.doi.org/10.1289/ehp.1003369.

29. Grabow ML, Spak SN, Holloway T, Stone B, Mednick AC,

Patz JA. Air quality and exercise-related health benefits from reduced car travel in the midwestern United States. Environ Health Perspect. 2012;120(1):68-76, http://dx.doi. org/10.1289/ehp.1103440.

This work is available in Open Access model and licensed under a Creative Commons Attribution-NonCommercial 3.0 Poland License - http://creativecommons.org/ licenses/by-nc/3.0/pl/deed.en. 